\title{
Debt Financing and Firm Performance: Evidence from an Emerging South-Asian Country
}

\author{
Mohammad Mazibar Rahman (Corresponding author) \\ Hajee Mohammad Danesh Science and Technology University \\ Dinajpur-5200, Bangladesh \\ Email: mazibar.act.hstu@gmail.com \\ Umme Khadija Kakuli \\ Hajee Mohammad Danesh Science and Technology University \\ Dinajpur-5200, Bangladesh \\ Email: kakuli1561@gmail.com \\ Shahnaz Parvin \\ Hajee Mohammad Danesh Science and Technology University \\ Dinajpur-5200, Bangladesh \\ Email: shahnazhstu09@gmail.com

\begin{abstract}
Ayrin Sultana
Hajee Mohammad Danesh Science and Technology University

Dinajpur-5200, Bangladesh

Email: runu.tonu@yahoo.com
\end{abstract}

Received: October 23, 2019 Accepted: November 14, 2019 Published: November 26, 2019 doi:10.5296/ber.v10i1.15910

URL: https://doi.org/10.5296/ber.v10i1.15910

\section{Abstract}

This paper aims to empirically investigate the impact of capital structure choice on the firm 
performance of the firms listed under the Dhaka Stock Exchange of Bangladesh. Multiple regression has been employed in this research to determine the relationship between the capital structure and the firm's financial performance. Three ratios of financial performance, i.e., return on assets, return on equity, and gross margin, have been used as a sample of non-financial Bangladeshi companies, selected from 2010 to 2015. The study records numerous findings. First, the result shows a significant negative influence of long-term debt (LTD) and total debt (TTD) on firm financial performance measured by return on assets (ROA), but no significant relationship is found between short-term debt (STD) and this measure of firm's financial performance. Moreover, the research found that there is no significant effect of short-term debt, long-term debt and total debt on the firm financial performance measured by return on equity (ROE). Finally, the result shows that a significant negative influence of short-term debt and total debt on firm performance measured by GM, but no significant relationship was found between long-term debt and financial performance. In general terms, the results of this study may suggest that capital structure has a negative influence on firms' financial performance in Bangladesh.

Keywords: Capital structure, Firm performance, Leverage, Accounting, Bangladesh

\section{Introduction}

Capital structure refers to the monetary framework of a firm that consists of combined debt, equity, and retained earnings. Additionally, capital structure means the amount of debt-equity that a company has employed to finance its operations and growth. In financial terms, capital structure indicates how a firm finances their property through combined equity, debt, or hybrid securities. Financial managers have to make three key financing decisions-investment, financing, and dividend payment, including capital structure decisions (Van Horne \& Wachowicz, 1995). Thus, if financing decision adds no value in the capital structure of firms, it is no longer some manager's concern. Evidence suggests that this event did not now maintain (Modigliani \& Miller, 1958).

A number of theories for instance the pecking order theory, the agency theory, and trade-off theory have advanced to provide an explanation for the capital structure choice of firms. However, researchers have not been able to locate the best capital structure for a firm due to the lack of consistency regarding what would be suitable as the best capital structure, which has required the need to conduct this research study. An exceptional thinking of the issue sheds some light on the idea of capital structure and its effect on firm financial performance. Various studies have been conducted on this topic in different countries. Margaritis and Psillaki (2010) found a significant positive effect between capital structure and a firm's efficiency. In their study, both low and high growing French firms were used as a sample. Capital structure, debt maturity, and performance of firms are influenced by the institutional surroundings in each developing and developed countries. Furthermore, firms in developing countries use more debt (Fan et al., 2012). However, the empirical proof for relationship between debt financing and firm's performance is inconsistent and varied. Though a positive relationship between debt level and firm's financial performance has been noted in some studies (Taub, 1975; Roden \& Lewellen, 1995; Ghosh et al., 2000; Hadlock \& James, 2002; 
Frank \& Goyal, 2003; Berger \& Patti, 2006), other studies document a negative relationship between them (Rajan \& Zingales, 1995; Fama \& French, 1998; Gleason et al., 2000; Simerly \& Li, 2000; Zertun \& Tian, 2007).

In the context of Bangladesh, this research is unique for the following reasons: i) The capital market in Bangladesh is less efficient than that in developed countries, and solid data about capital markets is not available to the public, particularly, the investors; ii) The capital market is still a value-based market. This may be because financing decisions are incomplete and lead to a big degree of irregularity.

The main objective of this research is to empirically investigate the relationship between leverage level and firms' financial performance of the selected non-financial companies of the Dhaka Stock Exchange during 2010-2015 using three financial ratios of financial performance: return on assets (ROA), return on equity (ROE), and gross margin (GM). In general terms, the results of this study recommend that there exists a negative influence between capital structure choice and firms' financial performance in Bangladesh.

\section{Literature Review}

Roden \& Lewellen (1995) stated that the company capital structure decision is taken with the purpose of explaining why the determined financing choice is made by an individual firm to accomplish the transactions. This is because financing selections are organized systematically to react to variations across firms in their plans to promote assets, in their income's variability, in their liquidity characteristics, and in their opportunity to attain tax saving from deductibility. Financing choice is an important matter to respond correctly for executing the transaction of the firm. The most regularly used performance measure variables are ROA, ROE, and ROI. Many researchers used these variables as accounting measures, representing financial ratios from income statement and balance sheet. Additionally, performance measure usefulness may affect the stock and capital market and the goal of a firm that ought to have an effect on its desire of performance measures. For example, market performance measure will now not provide an exact result if the stock market is no longer quite developed (Demsetz \& Lehn, 1985; Gorton \& Rosen, 1995; Mehran, 1995; Ang et al., 2000).

Generally, the capital structure choice of firm could be described by two main theories: the trade-off theory and the pecking order theory. As stated by the trade-off theory, the most optimum capital structure could be estimated with the aid of balancing various benefits and costs associated with debt financing. Debt benefits include tax shields (saving) caused via the deductibility of interest expenses from pre-tax income of the company (Modigliani \& Miller, 1963), discount of agency costs through the threat of liquidation, which motives personal losses to managers of salaries, reputation, and perquisites, and through the need to generate cash flow to pay interests (Williams, 1987). Furthermore, high leverage can increase the firm's performance with the aid of reducing disagreements between shareholders and directors regarding the free cash flow (Jensen, 1986), most appropriate funding approach (Myers, 1977), and the amount of risk to be undertaken (Jensen \& Meckling, 1976).

On the other hand, the pecking order theory developed by Myers \& Majluf (1984) point out 
that due to the information asymmetry between managers and investors regarding the investment opportunities of firms, the market may undervalue the price of the new share of firm that would be assessed if a manager exposes information related to investment opportunities to the share market. Thus, assigning new shares could put down the present shareholders over price allocation from long-standing to recent shareholders. Hence, managers will choose funding new investment by internal source, and if it is not enough, then managers will collect from external source. Thus, as stated by the pecking order theory, firms use less debt in their capital structure that are profitable and, therefore, make high earnings to be reserved than those who do not make high earnings, as the firms are highly capable to finance their investment prospects with retained earnings. Consequently, debt level has a negative relationship on a firm's performance (i.e., profitability). Many studies show in their empirical evidence that there is a positive relationship between capital structure choice and a firm's financial performance (Hadlock \& James, 2002; Berger \& Patti, 2006).

From the presented studies above, it can be clarified that developed countries conducted most of the research activities regarding the relationship between capital structure and a firm's financial performance. But, a limited number of studies examined empirically the relationship between capital structure and a firm's financial performance in emerging economies. Abor (2007) examined the effect of capital structure on profitability in the Ghana Stock Exchange listed firms for five years, result showing that there is positive relationship between short term debt to total assets and a negative relationship between long term debt to total assets and ROE. Furthermore, Kyereboah-Coleman (2007) investigated the connection between debt level and financial performance of microcredit organizations in Sub-Saharan Africa, the result illustrating that high debt level is positively correlated with firm's financial performance (return on equity and return on assets). Margaritis \& Psillaki (2007) investigated the correlation between firm efficiency and leverage of 12,240 New Zealand firms using a quantile regression analysis, whose results show that the inverse causality effect of effectiveness on leverage is positively related at low to mid-debt levels but negatively related at high debt ratios. Ebaid (2009) investigated performance of 64 Egyptian-listed firms over the period of 1997-2005 by using multiple regression analysis. The results suggested that there is a negative correlation among short-term debt and total debt to profitability in terms of return on assets (ROA). However, the study showed that short- or long-term debts have no significant relationship on profitability in terms of ROE and gross profit margin. Moreover, Sheikh \& Wang (2011) studied 240 listed Pakistani non-financial companies during the period of 2004-2009 and examined their influence of capital structure on the financial performance. Some statistical methods such as OLS and fixed effects and random effects were used in this study. The empirical results of this study showed that a negative correlation existed between long-term \& short-term debt ratios and ROA. Salim \& Yadav (2012) investigated the relationship between capital structure and firm performance of 237 Malaysian-listed companies during the period of $1995-2011$ by using the panel data procedure. The results showed that firm performance and earning per share (EPS) has a negative relationship with STD, LTD, TTD which are measured in term of ROA and ROE. Moreover, in all the sectors, there is a positive relationship between firm's growth and financial performance. Chadha \& Sharma (2015) studied 422 listed Indian manufacturing companies on the Bombay Stock 
Exchange (BSE) and tested the effect of capital structure on the firms' performance. The result showed that financial leverage has no impact on a firm's performance in term of return on asset (ROA) and Tobin's Q. However, the result is negative and significantly correlated with return on equity (ROE). Vătavu (2015) examined the correlation between capital structure and firm's financial performance over a period of eight years (2003-2010) in 196 Romanian manufacturing companies listed on the Bucharest Stock Exchange. The result of the study shows that Romanian companies' financial performance are higher when they use less debt and work based on equity. However, it appears that manufacturing companies in Romania lack of sufficient internal finance to undertake profitable investments options and do not utilize their assets properly. Yazdanfar \& Öhman (2015) investigated the correlation between debt level and financial performance of 15,897 Swedish SMEs which include five industry sub sectors during the period of 2009-2012. The result shows that debt ratios, short-term debt and long-term debt, negatively influence the firm financial performance in terms of ROA and ROE.

Indeed, experimental studies involving the relationship between capital structure and financial performance in the developed countries provide mixed and inconsistent evidence; however, a limited study empirically detected this relationship in developing economies like Bangladesh. This study provides a sound view of extended literature on the firm's capital structure choices by evaluating the relationship between capital structure and firm's financial performance in Bangladesh. In fact, Bangladesh is an exclusive instance for several logics such as the stock market in Bangladesh is less competent and suffers from higher level of information irregularity than stock markets in developed countries. Additionally, the capital market in Bangladesh is based on an equity market, and the debt market structure of this country is still very immature and incompetent. This environment of the market may lead to incomplete financing decisions and subject to a significant degree of irregularity. Therefore, it is very important to discover the soundness of debt financing and firms' financial performance relationship underneath these special economic environment settings.

\section{Methodology}

\subsection{Sample and Data}

In this study, all publicly traded companies listed on Dhaka Stock Exchange (DSE) are used for ratios calculation during the period of 2010-2015. Our sample has 12 sectors that consist of 191 individual quoted companies, of which 50 companies have been selected. Recorded companies of DSE database were then removed for considering several factors; the financial institutions were abandoned from the sample due to the nature of their financial statement, and the remaining companies were then calculated for available financial data in their websites. Financial services institutions include bank, corporate bond, debentures, insurance, mutual funds, treasury bond, etc. All data have been obtained by consulting DSE-listed companies' database. Table 1 provides the distribution of the sample by industry. 
Table 1. DISTRIBUTION OF THE SAMPLE BY INDUSTRY

\begin{tabular}{|l|c|}
\hline Industry Name & Number of companies \\
\hline Cement & 5 \\
\hline Ceramics Sector & 2 \\
\hline Food and Allied & 3 \\
\hline Fuel and Power & 5 \\
\hline IT Sector & 1 \\
\hline Pharmaceuticals and Chemicals & 9 \\
\hline Telecommunication & 1 \\
\hline Travel and leisure & 1 \\
\hline Engineering & 8 \\
\hline Service and Real Estate & 3 \\
\hline Tannery & 1 \\
\hline Textile & 11 \\
\hline Total & 50 \\
\hline
\end{tabular}

Source: https://www.dsebd.org/company\%20listing.php

\subsection{Variable Motivation and Description}

3.2.1 Performance: Literature uses various measures of a firm's financial performance, such as accounting ratios calculated from firm's consolidated financial statements, for example, ROE, ROA, and GM and Tobin's Q measures (Majumdar \& Chhibber, 1999; and Abor, 2005, 2007). This study has used three of the common accounting-based performance ratios, ROA, ROE, and GM, to evaluate the firm's financial performance.

3.2.2 Financial leverage: Related to past literature, financial leverage was examined in this study by three financial ratios (Abor, 2005, 2007): (i) Short-Term Debt to total assets; (ii) Long-Term Debt to total assets; (iii) Total Debt to total assets.

3.3.3 Control variable: By including the size variable in the model, this research controls the variations in a firm's operating environment. Size is calculated by the log of total assets of the firm and is comprised in the model to control for the effects of firm size.

The following ratios are calculated from the listed companies' financial statement: 
Table 2. ABBREVIATION OF FINANCIAL RATIOS

\begin{tabular}{|l|l|}
\hline Return on assets (ROA) & ROA $=\frac{\text { Net Income }}{\text { Total Asset }} \times 100$ \\
\hline Return on equity (ROE) & ROE $=\frac{\text { Net Income }}{\text { Shareholder Equity }} \times 100$ \\
\hline Gross Margin (GM) & GM $=\frac{\text { Gross Profit }}{\text { Revenue }} \times 100$ \\
\hline Short-Term Debt (STD) & STD $=\frac{\text { Current Liabilities }}{\text { Total Assets }} \times 100$ \\
\hline Long-Term Debt (LTD) & LTD $=\frac{\text { Long }- \text { term Debt }}{\text { Total Assets }} \times 100$ \\
\hline Total Debt Ratio (TD) & TD $=\frac{\text { Total Debt }}{\text { Total Assets }} \times 100$ \\
\hline
\end{tabular}

\subsection{Research Model}

The following regression models have used to test the relationship between leverage level and a firm's financial performance (Ebaid, 2009):

$$
\begin{aligned}
& \text { Performance }_{I, t}=\beta_{0}+\beta_{1}(\mathrm{STD})_{I, t}+\beta_{2} \log (T A)_{I, t}+\mathrm{ei}_{I, t} \\
& \text { Performance }_{I, t}=\beta_{0}+\beta_{I}(\mathrm{LTD})_{I, t}+\beta_{2} \log (T A)_{I, t}+\mathrm{ei}_{I, t} . \\
& \text { Performance }_{I, t}=\beta_{0}+\beta_{I}(\mathrm{TTD})_{I, t}+\beta_{2} \log (T A)_{I, t}+\mathrm{ei}_{I, t} .
\end{aligned}
$$

Where:

$\mathrm{STD}_{I, t}=$ Short-term debt to total assets for firm $I$ in year $t$.

$\mathrm{LTD}_{I, t}=$ Long-term debt to total assets for firm $I$ in year $t$.

$\mathrm{TTD}_{I, t}=$ Total debt to total assets for firm $I$ in year $t$.

$\log (T A)_{I, t}=\operatorname{logarithm}$ of total assets for firm $I$ in year $t$.

$\mathrm{ei}_{I, t}=$ the error term.

\section{Analysis and Discussion}

\subsection{Descriptive Statistics}

Table 3 presents a summary of the descriptive statistics of the dependent and independent variables used in this study. Descriptive statistics show mean, standard deviation, minimum, and maximum. First, the mean value of ROA, ROE, and GM are 0.0728, 0.1357, and 0.2866, respectively. The mean capital structures STD, LTD, and TD are about 0.4445, 0.0998 and 0.4544, respectively, which indicates that these results indicate that Bangladeshi-listed firms rely upon more largely on short-term debt (STD) for funding their operation than long-term 
debt (LTD). The extensive dependence on short-term debt rather than on long-term debt by Bangladeshi-listed firms may be a result of the nonappearance of a well-established public share market.

Table 3. DESCRIPTIVE STATISTICS

\begin{tabular}{|l|l|l|l|l|}
\hline Variable & Mean & ST. deviation & Minimum & Maximum \\
\hline ROA & 0.0728 & 0.0685 & -0.1228 & 0.3400 \\
\hline ROE & 0.1357 & 0.1388 & -0.5918 & 0.6435 \\
\hline GM & 0.2866 & 0.1702 & -0.1646 & 0.9957 \\
\hline STD & 0.4445 & 0.2602 & 0.0258 & 1.0000 \\
\hline LTD & 0.0998 & 0.1002 & -0.0002 & 0.5697 \\
\hline TD & 0.4544 & 0.2097 & 0.0008 & 0.9279 \\
\hline Log TA & 9.3658 & 0.9263 & 6.3500 & 11.0700 \\
\hline
\end{tabular}

Source: Authors own calculation

Thus, financing availability on long-term basis to Bangladeshi-listed firms is direct borrowing from banks and credit institutions. However, these sources are very hard to rely on in case of the very confining debt agreement faced by these firms as well. The data itself is taken from 2010 to 2015 comprise of 50 companies listed on the Dhaka Stock Exchange, but the age of the companies is different.

\subsection{Regression Results}

Table 4-6 show results of the relationship between debt level and a firm's performance using ordinary least squares regression formula. Table 4 represents the results of testing the ratio of short-term debt (STD) to total assets (Model no 1), the ratio of long-term debt (LTD) to total assets (Model no 2), the ratio of total debt (TD) to total assets (Model no 3), and firms' financial performance measured by return on assets (ROA).

Table 4. PERFORMANCE (ROA)

\begin{tabular}{|l|l|l|l|}
\hline Variable & Model 1 & Model 2 & Model 3 \\
\hline Constant & 0.239 & 0.236 & 0.275 \\
\hline STD & $-0.016(0.274)$ & & \\
\hline LTD & & $-0.087(0.023)$ & \\
\hline TTD & & & $-0.104(0.000)$ \\
\hline Log TA & $-0.170(0.000)$ & $-0.170(0.000)$ & $-0.170(0.000)$ \\
\hline$R^{2}$ & 0.055 & 0.068 & 0.153 \\
\hline F & 8.717 & 10.819 & 26.910 \\
\hline Sig. & 0.000 & 0.000 & 0.000 \\
\hline
\end{tabular}

As depicted in this table, the results show that there is a significant negative relationship between LTD and ROA; at the level of confidence of 95\%, the coefficient value of LTD in Model no 2 is negative and also statistically significant, which indicates that an increase 
amount in LTD is associated with a decrease amount in ROA. Additionally, the results also show that a significant negative relationship between TTD and ROA are existed; the coefficient value of TTD in Model no 3 is negative which is also statistically significant at the confidence level of $95 \%$. This result suggests that an increase value in TTD is directly associated with a decrease value in ROA. This effect may be because of LTD being the extensive number of capital structure of Bangladeshi firms. This suggests that an increase amount in the long-term debt position is related with a decrease in profitability.

Furthermore, this can be described by the fact that long-term debts are comparatively more expensive, and, therefore, using high percentages of them could lead to low level of profitability. On the other hand, in Table 4, no significant relationship is found in STD with ROA; the coefficient value of STD is not statistically significant in Model no 1 at $95 \%$ level of confidence. Consequently, the results suggest that firm performance (ROA) also negatively related with control variable (firm size).

As shown in Table 5, the results show that neither STD, LTD, nor TTD has a significant relationship with a firm's financial performance as examined by ROE; the coefficient value of STD in Model no 1, the coefficient value of LTD in Model no 2, and the coefficient value of TTD in Model no 3 are not statistically significant at 95\% level of confidence. Additionally, the results suggest that the control variable (firm size) and firm's performance have no significant effect with each other.

Table 5. PERFORMANCE (ROE)

\begin{tabular}{|l|l|l|l|}
\hline Variable & Model 1 & Model 2 & Model 3 \\
\hline Constant & 0.272 & 0.293 & 0.277 \\
\hline STD & $0.039(0.200)$ & & \\
\hline LTD & & $0.014(0.863)$ & \\
\hline TTD & & & $0.038(0.315)$ \\
\hline Log TA & $-0.016(0.058)$ & $-0.017(0.051)$ & $-0.017(0.050)$ \\
\hline $\mathrm{R}^{2}$ & 0.018 & 0.013 & 0.016 \\
\hline F & 2.740 & 1.920 & 2.418 \\
\hline Sig. & 0.066 & 0.148 & 0.091 \\
\hline
\end{tabular}

The results mentioned in Table 6 also suggests that STD and TTD have significant negative relationship with a firm's financial performance as examined by GM; the coefficient value of STD in Model no 1 and the coefficient value of TTD in Model no 3 are statistically significant at 95\%. confidence level. Instead, in Table 6, LTD in Model no 2 has no significant relationship with gross margin (GM). The control variable (firm size) has a significant effect on GM. 
Table 6. PERFORMANCE (GM)

\begin{tabular}{|l|l|l|l|}
\hline Variable & Model 1 & Model 2 & Model 3 \\
\hline Constant & 0.005 & -0.050 & 0.087 \\
\hline STD & $-0.103(0.005)$ & & \\
\hline LTD & & $-0.022(0.821)$ & \\
\hline TTD & & & $-0.325(0.000)$ \\
\hline Log TA & $0.035(0.001)$ & $0.036(0.001)$ & $0.037(0.000)$ \\
\hline$R^{2}$ & 0.063 & 0.039 & 0.199 \\
\hline F & 10.054 & 6.000 & 36.824 \\
\hline Sig. & 0.000 & 0.003 & 0.000 \\
\hline
\end{tabular}

\section{Conclusion}

The capital structure decision is important for any business organization. This decision is crucial because of the need to maximize return by minimizing the cost of capital and risk and the impact of the capital structure decision on a firm's capability to deal with its competitive situation. In this study, an extensive number literature review examines the implication of the capital structure preference on a firm's performance. Considerable number of these researches examined these models in the developed countries, but very few is empirically familiar with such implications in developing countries such as Bangladesh. This study investigates the impact of the capital structure choice on the performance of listed firms in Bangladesh and using total three financial performance ratios (ROA, ROE, and GM). The empirical result of the study shows that capital structure, particularly LTD and TTD, shakes negatively on a firm's financial performance as examined by ROA, but no significant relationship is found for STD and this measure of financial performance. On the other side, capital structure (STD, LTD, and TTD) has no significant effect on a firms' financial performance as examined by ROE. Again, capital structure (particularly, STD and TTD) shakes negatively on a firm's financial performance as examined by GM, but no significant relationship is found between LTD and this measure of firms' performance.

The empirical tests indicate that capital structure (LTD and TD) has negative significant influence on a firm's financial performance which is measured by ROA, and these results are consistent with that of Rajan and Zingales (1995), Zetun and Tian (2007), and Abor (2007), who showed that a firm's performance is negatively correlated to its capital structure. These finding are different with that of Taub (1975), Roden and Lewellen (1995), Ghosh et al. (2000), Hardlock and James (2002), Frank and Goyal (2003), and Berger and Patti (2006), who discovered that there is a positive correlation between firm financial performance and capital structure choice.

Standards should be established to measure the financial performance of firms so that firms can select their capital structure properly. The management of non-financial institutions in the Dhaka Stock Exchange should strive toward achieving an optimal capital structure by increasing their debt level and reducing dependence on equity. Further research could be conducted with the addition of new variables or other market-based measures to test the 
relationship of capital structure on firm performance, which can expose some new findings from Bangladeshi firms.

\section{References}

Abor, J. (2005). The effect of capital structure on profitability: An empirical analysis of listed firms in Ghana. Journal of Risk Finance, 6(5), 438-447.

https://doi.org/10.1108/15265940510633505

Abor, J. (2007). Debt policy and performance of SMEs: Evidence from Ghanaian and South Africa firms. The Journal of Risk Finance, 8(4), 364-379.

https://doi.org/10.1108/15265940710777315

Ang, J. S., Cole, R. A., \& Lin, J. W. (2000). Agency costs and ownership structure. The Journal of Finance, 55(1), 81-106. https://doi.org/10.1111/0022-1082.00201

Berger, A. N., \& Patti, E. B. (2006). Capital structure and firm performance: A new approach to testing agency theory and an application to the banking industry. Journal of Banking \& Finance, 30(4), 1065-1102. https://doi.org/10.1016/j.jbankfin.2005.05.015

Chadha, S., \& Sharma, A. K. (2015). Capital structure and firm performance: Empirical evidence from India. The Journal of Business Perspective, 19(4), 295-302.

https://doi.org/10.1177/0972262915610852

Demsetz, H., \& Lehn, K. (1985). The structure of corporate ownership: Causes and consequences. Journal of Political Economy, 93(6), 1155-1177.

https://doi.org/10.1086/261354

Ebaid, I. E. (2009). The impact of capital - structure choice on firm performance: Empirical evidence from Egypt. The Journal of Risk Finance, 10(5), 477-487.

https://doi.org/10.1108/15265940911001385

Fama, E. F., \& French, K. R. (1998). Taxes, financing decisions, and firm value. The Journal of Finance, 53(3), 819-843. https://doi.org/0.1111/0022-1082.00036

Fan, J., Titman, S., \& Twite, G. (2012). An international comparison of capital structure and debt maturity choices. Journal of Financial and Quantitative Analysis, 47(1), 23-56.

https://doi.org/10.1017/S0022109011000597

Frank, M., \& Goyal, V. (2003). Testing the pecking order theory of capital structure. Journal of Financial Economics, 67(2), 217-248. https://doi.org/10.1016/S0304-405X(02)00252-0

Ghosh, C., Nag, R., \& Sirmans, C. F. (2000). The pricing of seasoned equity offerings: Evidence from REITs. Real Estate Economics, 28(3), 363-384.

https://doi.org/10.1111/1540-6229.00805

Gleason, K. C., Mathur, L. K., \& Mathur, I. (2000). The interrelationship between culture, capital structure, and performance. Journal of Business Research, 50(2), 185-191.

https://doi.org/10.1016/S0148-2963(99)00031-4 
Gorton, G., \& Rosen, R. (1995). Corporate control, portfolio choice, and the decline of banking. The Journal of Finance, 50(5), 1377-1420.

https://doi.org/10.1111/j.1540-6261.1995.tb05183.x

Hadlock, C. J., \& James, C. M. (2002). Do banks provide financial slack? The Journal of Finance, 57(3), 1383-1419. https://doi.org/10.1111/1540-6261.00464

Jensen, M. C. (1986). Agency costs of free cash flow, corporate finance and takeovers. The American Economic Review, 76(2), 323-329.

Jensen, M. C., \& Meckling, W. H. (1976). Theory of the firm, managerial behavior, agency costs and ownership structure. Journal of Financial Economics, 3(4), 305-360.

https://doi.org/10.1016/0304-405X(76)90026-X

Kyereboah-Coleman, A. (2007). The impact of capital structure on the performance of microfinance institutions. Journal of Risk Finance, 8(1), 56-71.

https://doi.org/10.1108/15265940710721082

Margaritis, D., \& Psillaki, M. (2007). Capital structure and firm efficiency. Journal of Business Finance \& Accounting, 34(9-10), 1447-1469.

https://doi.org/10.1111/j.1468-5957.2007.02056.x

Margaritis, D., \& Psillaki, M. (2010). Capital structure, equity ownership and firm performance. Journal of Banking \& Finance, 34(3), 621-632.

https://doi.org/10.1016/j.jbankfin.2009.08.023

Mehran, H. (1995). Executive compensation structure, ownership, and firm performance. Journal of Financial Economics, 38(2), 163-184.

https://doi.org/10.1016/0304405X(94)00809F

Modigliani, F., \& Miller, M. (1963). Corporate income taxes and the cost of capital: a correction. American Economic Review, 53, 443-453.

Myers, S. C. (1977). Determinants of corporate borrowings. Journal of Financial Economics, 5(2), 147-175. https://doi.org/10.1016/0304-405X(77)90015-0

Myers, S. C., \& Majluf, N. S. (1984). Corporate financing and investment decisions when firms have information that investors do not have. Journal of Financial Economics, 13(2), 187-221. https://doi.org/10.1016/0304-405X(84)90023-0

Rajan, R. G., \& Zingales, L. (1995). What do we know about capital structure? Some evidence from international data. Journal of Finance, 50(5), 1421-1460.

https://doi.org/10.1111/j.15406261.1995.tb05184.x

Roden, D. M., \& Lewellen, W. G. (1995). Corporate capital structure decisions: Evidence from leveraged buyouts. Financial Management, 24(2), 76-87.

https://doi.org/10.2307/3665536

Salim, M., \& Yadav, R. (2012). Capital structure and firm performance: Evidence from Malaysian listed companies. Procedia - Social and Behavioral Sciences, 65, 156-166. 
https://doi.org/10.1016/j.sbspro.2012.11.105

Simerly, R. L., \& Li, M. (2000). Environmental dynamism, capital structure and performance: A theoretical integration and an empirical test. Strategic Management Journal, 21(1), 31-49. https://doi.org/10.1002/(SICI)1097-0266(200001)21:1<31::AID-SMJ76>3.0.CO;2-T

Sheikh, N. A., \& Wang, Z. (2011). Determinants of capital structure: An empirical study of firms in manufacturing industry of Pakistan. Managerial Finance, 37(2), 117-133. https://doi.org/10.1108/03074351111103668

Taub, A. J. (1975). Determinants of the firm's capital structure. The Review of Economics and Statistics, 57(4), 410-416. https://doi.org/10.2307/1935900

Van Horne, J. C., \& Wachowicz, J. M. (1995). Fundamentals of financial management. Englewood Cliffs, NJ: Prentice Hall.

Vătavu, S. (2015). The impact of capital structure on financial performance in Romanian listed companies. Procedia Economics and Finance, 32, 1314-1322.

https://doi.org/10.1016/S22125671(15)01508-7

Williams, J. (1987). Perquisites, risk, and capital structure. The Journal of Finance, 42(1), 29-49. https://doi.org/10.1111/j.1540-6261.1987.tb02548.x

Yazdanfar, D., \& Öhman, P. (2015). Debt financing and firm performance: An empirical study based on Swedish data. The Journal of Risk Finance, 16(1), 102-118.

https://doi.org/10.1108/JRF06-2014-0085

Zeitun, R., \& Tian, G. (2007). Capital structure and corporate performance: Evidence from Jordan. The Australasian Accounting Business and Finance Journal, 1, 40-53.

https://doi.org/10.2139/ssrn.2496174

\section{APPENDIX}

Listed Companies of Dhaka Stock Exchange

\begin{tabular}{|l|l|l|}
\hline \multicolumn{1}{|c|}{ Industry } & \multicolumn{1}{|c|}{ DSE Code } & \multicolumn{1}{c|}{ Listed Company } \\
\hline \multirow{5}{*}{ Cement } & CONFIDCEM & Confidence Cement Limited \\
\cline { 2 - 3 } & HEIDELBCEM & Heidelberg Cement Bangladesh \\
\cline { 2 - 3 } & MICEMENT & M.I. Cement Factory Limited \\
\cline { 2 - 3 } & LHBL & Lafarge Surma Cement Limited \\
\cline { 2 - 3 } & PREMIERCEM & Premier Cement Mills Limited \\
\hline \multirow{4}{*}{ Ceramics } & RAKCERAMIC & RAK Ceramics (Bangladesh) Limited \\
\cline { 2 - 3 } & SPCERAMICS & Shinepukur Ceramics Limited \\
\hline \multirow{5}{*}{ Fuel and Allied } & APEXFOODS & Apex Foods Limited \\
\cline { 2 - 3 } & BATBC & British American Tobbaco Bangladesh Company \\
\cline { 2 - 3 } & OLYMPIC & Olympic Industries Limited \\
\hline
\end{tabular}




\begin{tabular}{|c|c|c|}
\hline & DESCO & Dhaka Electric Supply Company Limited \\
\hline & KPCL & Khulna Power Company Limited \\
\hline & LINDEBD & Linde Bangladesh Limited \\
\hline & SUMITPOWER & Summit Power Limited \\
\hline IT Sector & BDCOM & BDCOM Online Limited \\
\hline \multirow[t]{9}{*}{ Pharmaceuticals and Chemicals } & ACIFORMULA & ACI Formulations Limited \\
\hline & BEACONPHAR & Beacon Pharmaceuticals Limited \\
\hline & BXPHARMA & Beximco Pharmaceuticals Limited \\
\hline & IBNSINA & Ibn Sina Pharmaceutical Industry Limited \\
\hline & IMAMBUTTON & Imam Button Industries Limited \\
\hline & LIBRAINFU & Libra Infusions Limited \\
\hline & ORIONINFU & Orion Infusions Limited \\
\hline & RENATA & Renata Limited \\
\hline & SQURPHARMA & Square Pharmaceuticals Limited \\
\hline Telecommunication & GP & Grameenphone Limited \\
\hline Travel and leisure & UNIQUEHRL & Unique Hotel \& Resorts Limited \\
\hline \multirow[t]{8}{*}{ Engineering } & BDLAMPS & Bangladesh Lamp Limited \\
\hline & BSRMSTEEL & BSRM Steel Limited \\
\hline & DESHBANDHU & Deshbondhu Polymer Limited \\
\hline & AFTABAUTO & Aftab Automobiles Limited \\
\hline & BENGALWTL & Bengal Windsor Thermoplastics Limited \\
\hline & QUASEMIND & Quasem Drycells Limited \\
\hline & NAVANACNG & Navana CNG Limited \\
\hline & SALAMCRST & S. Alam Cold Rolled Steels Ltd \\
\hline \multirow[t]{3}{*}{ Service and Real Estate } & EHL & Eastern Housing Limited \\
\hline & SAPORTL & Summit Alliance Port Limited \\
\hline & SAIFPOWER & SAIF Powertec Limited \\
\hline Tannery & APEXFOOT & Apex Footwear Limited \\
\hline \multirow[t]{11}{*}{ Textile } & ANLIMAYARN & Anlimayarn Deying Limited \\
\hline & APEXSPINN & Apex Spinning \& Knitting Mills Limited \\
\hline & FEKDIL & Far East Knitting \& Dyeing Industries Limited \\
\hline & GENNEXT & Generation Next Fashions Limited \\
\hline & MATINSPINN & Matin Spinning Mills Limited \\
\hline & RAHIMTEXT & Rahim Textile Mills Limited \\
\hline & SAIHAMCOT & Saiham Cotton Mills Limited \\
\hline & SQUARETEXT & Square Textile Limited \\
\hline & HWAWELLTEX & Hwa Well Textiles (BD) Limited \\
\hline & RNSPIN & R.N. Spinning Mills Limited \\
\hline & SAIHAMTEX & Saiham Textile Mills Limited \\
\hline
\end{tabular}




\section{Copyright Disclaimer}

Copyright for this article is retained by the author(s), with first publication rights granted to the journal.

This is an open-access article distributed under the terms and conditions of the Creative Commons Attribution license (http://creativecommons.org/licenses/by/3.0/). 